JSAP: Journal Syariah and Accounting Public

ISSN: 2622-3538

Available Online at https://journal.umgo.ac.id/index.php/JSAP/index

Vol. 4, No. 1 Juli 2021

DOI: $10.31314 /$ jsap.4.1.24-30.2021

\title{
PENERAPAN PSAP NO. 01 DALAM PERTANGgUNGJAWABAN KEUANGAN DI DESA PENTADIO TIMUR
}

\author{
Maryam Noho ${ }^{1}$, Yuwin Ali $^{2}$ \\ 1,2, Program Studi Akuntansi Fakultas Ilmu Sosial Universitas Muhammadiyah Gorontalo \\ Email; dewi.maryam.14@yahoo.co.id, yuwinali@umgo.ac.id
}

Info Artikel: Diterima: 13 Nov. 2019, Disetujui: 17 Februari 2020, Publish 15 Juli 2021

\begin{abstract}
:
This study aims to determine the application of the Governmental Accounting Standard Statement (PSAP) No. 01 In Village Financial Accountability in Pentadio Timur Village, Telaga Biru District, Gorontalo District. This type of research uses descriptive research with a qualitative approach by Nazir (2009). The results of this study are that the financial accountability reporting in Pentadio Timur Village, Telaga Biru District, Gorontalo Regency is in accordance with the Minister of Home Affairs Regulation Number 20 of 2018 in the fifth part of article 70 regarding Village financial accountability and is based on the Government Accounting Standards Statement (PSAP) No. 01. However, it is not yet fully in accordance with the implementing regulations. Where the Village Government has only made four of the seven rules of financial accountability reports, while in the regulation on Implementation of PSAP No. 01 it has 7 (tuju) components of the rules. In this case, it is hoped that the Government will make a village financial accountability report in accordance with Government Regulation Number 71 of 2010 based on PSAP No. 01 by completing the components of financial statements in order to create accountable and transparent financial reports.
\end{abstract}

Keywords: Accounting, PSAP, Village

\begin{abstract}
Abstrak:
Penelitian ini bertujuan untuk mengetahui Penerapan Pernyataan Standar Akuntansi Pemerintahan (PSAP) No. 01 Dalam Pertanggungjawaban Keuangan Desa Di Desa Pentadio Timur Kecamatan Telaga Biru Kabupaten Gorontalo. Jenis penelitian ini menggunakan jenis penelitian deksriptif dengan pendekatan kualitatif oleh Nazir (2009). Hasil penelitian ini adalah pelaporan pertanggungjawaban keuangan di Desa Pentadio Timur sudah sesuai dengan Peraturan Mentri Dalam Negeri Nomor 20 Tahun 2018 pada bagian kelima pasal 70 tentang pertanggungjawaban keuangan Desa dan sudah berdasarkan PSAP No. 01. Namun belum sepenuhnya sesuai dengan aturan penerapannya. Dimana Pemerintah Desa baru membuat empat dari tujuh aturan laporan pertanggungjawaban keuangan sementara dalam aturan Penerapan PSAP No.01 memiliki 7 komponen aturan. Dalam hal ini diharapkan Pemerintah dalam membuat laporan pertanggungjawaban keuangan Desa agar dapat sesuai dengan Peraturan Pemerintah Nomor 71 Tahun 2010 berdasarkan PSAP No.01 dengan melengkapi komponen-komponen laporan keuangan guna menciptakan laporan keuangan yang akuntabel dan transparan.
\end{abstract}

Kata kunci : Akuntansi, PSAP, Desa 


\section{PENDAHULUAN}

. Upaya Pemerintah untuk memberikan pelayanan kepada Masyarakat diwujudkan dengan pencapaian kinerja sebagaimana komitmen yang telah ditetapkan melalui perbaikan kinerja Pemerintah. Dalam hal ini Pemerintah dapat melakukan komunikasi dua arah dengan Masyarakat guna untuk mencari titik temu pemecahan permasalahan yang terjadi. Hal tersebut menjadi isyarat bahwa untuk mewujudkan suatu pemerintahan yang responsif, bebas KKN serta berkinerja, kondisi akuntabilitas merupakan kondisi yang harus ada untuk dipenuhi, dalam rangka mewujudkan hal tersebut, perlu dipadukan pengembangan dan penerapan sistem pertanggungjawaban yang tepat, jelas, dan nyata sehingga penyelenggaraan pemerintah dan pembangunan dapat berlangsung secara berdaya guna, berhasil guna, bersih, bertanggung jawab, dan bebas dari Kolusi, Korupsi dan Nepotisme (KKN), yang dalam penerapannya adalah membuat suatu tata cara penyelenggaraan pemerintah yang baik atau yang lebih dikenal dengan istilah Good Governance (Apriyono, 2010).

Reformasi dibagian keuangan Negara perlu dilakukan perubahan diberbagai bidang untuk mendukung reformasi agar dapat berjalan dengan baik. Menurut Renyowijoyo (2008), yaitu salah satu perubahan di bidang akuntansi pemerintahan, karena melalui proses akuntansi dihasilkan informasi keuangan untuk berbagai pihak, agar digunakan sesuai dengan tujuan masing-masing. Perubahan di bidang akuntansi pemerintahan yang paling diinginkan yaitu adanya standar akuntansi pemerintahan. Penyusunan laporan keuangan yang berpedoman pada standar akuntansi pemerintah sesungguhnya adalah dalam rangka peningkatan kualitas laporan keuangan, sehingga laporan keuangan yang dimaksud dapat meningkatkan kredibilitasnya dan dapat mewujudkan transparansi dan akuntabilitas pengelolaan keuangan pemerintah daerah. Transparansi tersebut dapat diwujudkan dengan melakukan reformasi dalam bidang Akuntansi Pemerintahan.

$$
\text { Dalam Prinsip Akuntansi }
$$

Pemerintahan yaitu Transparansi dan juga Akuntabilitas dalam pengelolaan keuangan publik tidak hanya sebagai bentuk kewajiban dari Pemerintah Pusat namun kewajiban dari suatu daerah khususnya Desa. Pemerintah Desa sebagai unit organisasi pemerintah yang berhadapan langsung dengan masyarakat dengan segala latar belakang kepentingan dan kebutuhannya memiliki peranan yang sangat penting. Akuntansi Desa sendiri menyatakan bahwa adanya keharusan dalam menyusun laporan pertanggungjawaban pengelolaan keuangan di Desa. Hal ini berdasarkan Peraturan Menteri Dalam Negeri Nomor 20 Tahun 2018 tentang pedoman pengelolaan keuangan Desa. Berdasarkan kewenangan tersebut, maka secara hukum Pemerintah Desa wajib melaporkan kinerjanya kepada Pemerintah Pusat dan kepada Masyarakat, Lubis, (2019).

Dalam pengeloaan tersebut dibuatlah Standar Akuntansi yang menjadi acuan dan pedoman bagi para akuntan yang berada dalam organisasi sektor publik. Sebagaimana tertera pada Peraturan Pemerintah Nomor 24 Tahun 2005 tentang Standar Akuntasi Pemerintah dan mengalami perubahan dengan terbitnya peraturan baru pemerintah Nomor 71 Tahun 2010 tentang Standar Akuntansi Pemerintahan (SAP) bertujuan meningkatkan kualitas pertanggung jawaban keuangan Pemerintah. Perubahan dari SAP sebelumnya ini mewajibkan akuntansi berbasis akrual (accrual) untuk 
Pemerintahan, termasuk pemerintahan daerah, dari yang sebelumnya hanya menggunakan akuntansi berbasis kas menuju akrual (Cash Toward Accrual). Ditinjau dari peneliti terdahulu dalam Penerapan SAP sangat berpengaruh positif terhadap kualitas penyajian laporan keuangan di Dinas Pendapatan Pengelolaan Keuangan dan Aset Daerah (DPPKAD) Kabupaten Gorontalo. Dimana Hasil Analisisi Determinasi menunjukan variabel dependen (Kualitas laporan keuangan) mampun dijelaskan oleh variabel independen (penerapan SAP), oleh Sako dan Lantowa,(2018). Adapun Entitas pelaporan penyajian laporan keuangan berdasarkan PSAP No. 01 yaitu: 1. Laporan Realisasi Anggaran (LRA) 2. Laporan Perubahan Awal Saldo Anggran Lebih. 3. Neraca 4. Laporan Operasional. 5. Laporan Arus Kas (LAK) 6. Laporan Perubahan Ekuitas, dan 7. Catatan atas Laporan Keuangan

Namun Penerapan Penyataan Standar Akuntansi Pemerintah (PSAP) No. 01 ini belum sepenuhnya dilaksanakan sehingga laporan keuangan yang dihasilkan belum diselenggarakan sesuai dengan Pernyataan Standar Akuntasi Pemerintahan, hal ini dibuktikan dengan masih banyaknya instansi pemerintah yang laporan keuangannya masih terdapat beberapa temuan oleh audit, baik audit intern maupun audit ekstern. Salah satunya adalah Desa Pentadio Timur Kecamatan Telaga Biru Kabupaten Gorontalo. Berdasarkan obsevasi awal yang peneliti lakukan di Desa Pentadio Timur peneliti menemukan bahwa Desa pentadio timur pada tahun 2015 sudah mulai menerapkan PSAP No.01, Tentunya Penerapan ini masi terbilang sangat baru yang berdampak pada kesiapan para pengelola keuangan tersebut, menyebabkan laporan keuangannya belum sesuai dengan Pernyataan

Akuntansi
Pemerintahan No. 01, dimana Desa tersebut hanya membuat empat laporan dari ketujuh peraturan PSAP No. 01 diantaranya:1) Laporan Realisasi Anggaran, 2) Neraca, 3) Laporan Arus Kas, dan pada bulan maret tahun 2020 Desa tersebut baru membuat 4) Catatan Atas Laporan Keuangan (CALK).

\section{METODE PENELITIAN}

Peneliti menggunakan jenis penelitian deskriptif kualitatif. Berkaitan dengan pengumpulan data penelitian, ada tiga proses yang akandilakukan oleh penelitian, sebagai berikut:1) Observasi, 2) Wawancara, 3) Dokumentasi. Analisis data penelitian kualitatif ini mengunakan analis data menurut Miles dan Huberman (2008) ada tiga macam kegiatan dalam analisis data kualitatif, yaitu, Pengumpulan Data, Penyajian Data, Penarikan Verifikasi Kesimpulan.

\section{HASIL DAN PEMBAHASAN}

Penelitian ini bertujuan untuk mengetahui penerapan Pernyataan Standar Akuntansi Pemerintahan (PSAP) No.1 Dalam Pertanggungjawaban Keuangan Desa Di Desa Pentadio Timur, Kecamatan Telaga Biru, Kabupaten Gorontalo. Dalam penelitian ini, peneliti menggunakan Pertanggungjawaban Keuangan Desa Menurut Permendagri Nomor 20 Tahun 2018.

Hasil penelitian yang diperoleh melalui observasi, wawancara mendalam dan dokumentasi dapat dideskripsikan sebagai berikut:

1. Kepala Desa menyampaikan laporan pertanggungjawaban realisasi APB Desa kepada Bupati/WaliKota melalui camat setiap akhir tahun anggaran.

Hasil wawancara peneliti dengan Sekertaris Desa menyatakan bahwa: 
"lya Pastinya, setiap akhir tahun, pada akhir masa tahunan sekali kami pihak pemerintah Desa melaporkan realisasi laporan pertanggungjawaban". (Wawancara NH Pukul 10.13 Tanggal 05 /Oktober/2020).

2. Laporan pertanggungjawaban sebagaimana dimaksud pada ayat (1) disampaikan paling lambat 3 (tiga) bulan setelah akhir tahun anggaran berkenaan yang ditetapkan dengan Peraturan Desa.

Hasil wawancara peneliti dengan Kepala Desa menyatakan bahwa:

"Iya mengenai pelaporan pertanggungjawaban keuangan selalu rutin kami sampaikan selambat-lambatnya tiga bulan pada awal tahun". (Wawancara RA Pukul 09.30 Tanggal 08/ Oktober/2020).

3. Peraturan Desa sebagaimana dimaksud pada ayat (2) disertai dengan: Laporan keuangan, terdiri atas: laporan realisasi APB Desa; dan catatan atas laporan keuangan; laporan realisasi kegiatan; dan daftar program sektoral, program daerah dan program lainnya yang masuk ke Desa

Hasil wawancara peneliti dengan Sekertaris Desa menyatakan bahwa:

"Banyak yang sudah kami buat, yang pertama Laporan Realisasi APBDesa, Laporan Realisai Anggaran Desa, Laporan, laporan Realisasi Anggaran Desa per Kegiatan, laporan Realisasi Anggaran Bulanan, laporan Realisasi Anggaran Triwulaan, laporan Realisasi Anggaran Semesteran, laporan Realisasi APBDes Semesteran, Laporan Kekayaan Milik Desa, laporan Realisasi APBDes per Sumberdana 1a, laporan Realisasi APBDes per Sumberdana 1b, Laporan Realisasi penggunaan Dana Desa, Laporan Penyerapan Dana Desa PMK 225 dan pada tahun 2020 kami baru saja membuat Catatan Atas Laporan Keuangan. Semuanya kami buat sudah dalam sistem yaitu SISKEUDES, Kami menggunakan Siskeudes mulai dari tahun 2018 sampai dengan sekarang. (Wawancara YY Pukul 13.45 Tanggal 06/Oktober/2020).
Peraturan Mentri Dalam Negeri Nomor 20 Tahun 2018 tentang pengelolaan keuangan Desa digunakan oleh Desa dalam menyusun APBDes dan melakukan pengelolaan keuangan Desa. Dalam penelitian ini peneliti menggunakan pemendagri No. 20 Tahun 2018 dalam bagian kelima pasal 70 sebagai acuan guna Untuk mengetahui Penerapan Pernyataan Standar Akuntansi Pemerintahan (PSAP) No. 01 Dalam Pertanggungjawaban Keuangan Desa Di Desa Pentadio Timur, Kecamatan Telaga Biru, Kabupaten Gorontalo.

1. Kepala Desa menyampaikan laporan pertanggungjawaban realisasi APB Desa kepada Bupati/WaliKota melalui camat setiap akhir tahun anggaran.

Secara garis besar Penerapan Pernyataan Standar Akuntansi Pemerintahan (PSAP) No. 01 di Desa Pentadio Timur Kecamatan Telaga Biru Kabupaten Gorontalo dilihat dari pasal 70 (Kepala Desa menyampaikan laporan pertanggungjawaban realisasi APB Desa kepada Bupati/WaliKota melalui camat setiap akhir tahun anggaran) sudah sesuai dengan kriteria yang ditetapkan dalam pemendagri tersebut.

Sebagai mana hasil observasi awal peneliti lakukan di Desa Pentadio Timur Kecamatan Telaga Biru, peneliti menemui bahwa Kepala Desa telah menyampaikan laporan pertanggung keuangan setiap tahunnya.

Kemudian berdasarkan keseluruhan wawancara yang peneliti dapatkan serta hasil analisis peneliti bahwa dalam pemerintahan Desa Pentadio Timur Kecamatan Telaga Biru telah benar-benar sesuai dengan Peraturan Mentri Dalam Negeri No. 20 Tahan 2018.

Dari uraian diatas dapat disimpulkan bahwa Desa Pentadio Timur Kecamatan 
Telaga Biru Kabupaten Gorontalo sudah sesuai dengan pasal 70 ayat 1 Peraturan Mentri Dalam Negeri dimana kepala pemerintahan Desa yakni Kepala Desa benar-benar telah menyampaikan Realisasi Anggaran Pendapatan Belanja Daerah disetiap tahunnya yang juga disampaikan kepada Badan Permusyawaratan Desa sebagai perwakilan dari Masyarakat.

\section{Laporan pertanggungjawaban} sebagaimana dimaksud pada ayat (1) disampaikan paling lambat 3 (tiga) bulan setelah akhir tahun anggaran berkenaan yang ditetapkan dengan Peraturan Desa.

Dilihat dari segi waktu pelaporan pertanggungjawaban, sebagaimana yang tercantum dalam pasal 70 ayat 1 (Laporan pertanggungjawaban sebagaimana dimaksud pada ayat (1) disampaikan paling lambat 3 (tiga) bulan setelah akhir tahun anggaran berkenaan yang ditetapkan dengan Peraturan Desa) Bahwa:

Berdasarkan observasi awal yang peneliti lakukan, peneliti menemukan Pemerintah Desa Pentadio Timur Kecamatan Telaga Biru telah membuat pelaporan pertanggungjawaban keuangan yang dilaporkan setiap akhir tahun namun Pemerintah Desa mengalami kendala dalam pembuatan pelaporan tersebut karena peraturan pencatatan buku kas umum yang sering mengalami perubahan disetiap tahunnya.

Kemudian berdasarkan keseluruhan wawancara yang peneliti lakukan serta analisis peneliti, peneliti menemukan bahwa Desa Pentadio Timur Kecamatan Telaga Biru telah melaksanakan pelaporan pertanggung jawaban keuangan di akhir tahun, dimana pemerintah menyampaiakan laporan pertanggungjawaban paling lambat 3 bulan setelah akhir tahun sebagaimana tercantum pada pasal 70 ayat 2 Peraturan
Mentri Dalam Negeri No. 70, namun Pemerintah Desa terkendala oleh waktu karena pembuatan laporan pertanggungjawaban memerlukan waktu yang tidak sedikit serta dengan peraturan pencatatan buku kas umum yang sering mengalami perubahan di setiap tahunnya menyebabkan Pemerintah Desa sulit menyesuaikan pelaporan pertanggung jawabannya. Hal ini juga berdampak pada penerapan PSAP No.01 tidak maksimal.

Dari uraian diatas dapat disimpulkan bahwa Desa Pentadio Timur Kecamatan Telaga Biru terkait dengan waktu Pelaporan Pertanggungjawaban Keuangan Desa sudah berdasarkan Peraturan Dalam Negeri ayat 2 Nomor 20 Tahun 2018 yakni Laporan pertanggungjawaban sebagaimana dimaksud pada ayat (1) disampaikan paling lambat 3 (tiga) bulan setelah akhir tahun anggaran berkenaan yang ditetapkan dengan Peraturan Desa. Namun belum sesuai dengan PSAP No.01 dimana masih terkendala oleh adanya peraturan pencatatan buku kas umum yang sering berubah-ubah setiap tahunnya.

3. Peraturan Desa sebagaimana dimaksud pada ayat (2) disertai dengan: Laporan keuangan, terdiri atas: laporan realisasi APB Desa; dan catatan atas laporan keuangan; laporan realisasi kegiatan; dan daftar program sektoral, program daerah dan program lainnya yang masuk ke Desa

Berdasarkan observasi awal yang peneliti lakukan, peneliti menemui bahwa Pemerintah Desa Pentadio Timur Kecamatan Telaga Biru sudah membuat laporan pertanggung jawaban keuangan berdasarkan acuan PSAP No.01, namun pelaporan pertanggunggjawaban keuangannya belum sepenuhnya sesuai dengan aturan PSAP No.01 yang ada. 
Kemudian berdasarkan hasil keseluruhan wawancara di atas serta hasil analisis peneliti, peneliti mendapatkan bahwa Desa Pentadio Timur Kecamatan Telaga Biru telah membuat laporan pertanggungjawaban berdasarkan Penerapan PSAP No.01, akan tetapi dalam pembuatan laporan pertanggungjawaban tersebut Pemerintah Desa baru membuat empat dari tujuh aturan pelaporan pertanggungjawaban keuangan Desa yaitu 1) Laporan Realisasi Anggaran, 2) Neraca, 3) Laporan Arus Kas, dan pada bulan maret tahun 2020 Desa tersebut baru membuat 4) Catatan Atas Laporan Keuangan (CALK), sementara dalam aturan Penerapan PSAP No.01 meliputi tujuh aturan, yaitu: 1) Laporan Realisasi Anggaran (LRA) 2) Laporan Perubahan Awal Saldo Anggran Lebih 3) Neraca 4) Laporan Operasional 5) Laporan Arus Kas (LAK) 6) Laporan Perubahan Ekuitas, dan 7) Catatan atas Laporan Keuangan.

Dari uraian diatas dapat di simpulkan bahwa Desa Pentadio Timur dalam pelaporan pertanggungjawaban Keuangan sudah sesuai dengan Permendagri No. 20 tahun 2020. Namun Pelaporan pertanggungjawban keuangan Desa Pentadio Timur belum sepenuhnya sesuai dengan PSAP No. 01 dimana Desa hanya membuat empat dari tujuh aturan pelaporan pertanggungjawaban keuangan Desa yaitu 1) Laporan Realisasi Anggaran, 2) Neraca, 3) Laporan Arus Kas, sementara dalam aturan Penerapan PSAP No.01 meliputi tujuh aturan, yaitu: 1) Laporan Realisasi Anggaran (LRA) 2) Laporan Perubahan Awal Saldo Anggran Lebih 3) Neraca 4) Laporan Operasional 5) Laporan Arus Kas (LAK) 6) Laporan Perubahan Ekuitas, dan 7) Catatan atas Laporan Keuangan.

\section{KESIMPULAN}

Berdasarkan hasil penelitian dan analisis yang telah peneliti uraikan pada bab sebelumnya tentang Penerapan Pernyataan Standar Akuntansi Pemerintahan (PSAP) No.01 mengggunakan teori Pemendagri Nomor 20 tahun 2018, maka dapat ditarik kesimpulan, bahwa:

Desa Pentadio Timur Kecamatan Telaga Biru Kabupaten Gorontalo sudah sesuai dengan pasal 70 ayat 1 Peraturan Mentri Dalam Negeri dimana kepala pemerintahan Desa yakni Kepala Desa benar-benar telah menyampaikan Realisasi Anggaran Pendapatan Belanja Daerah disetiap tahunnya yang juga disampaikan kepada Badan Permusyawaratan Desa sebagai perwakilan dari Masyarakat. Selanjutnya terkait dengan waktu Pelaporan Pertanggungjawaban Keuangan Desa sudah berdasarkan Peraturan Dalam Negeri ayat 2 Nomor 20 Tahun 2018 yakni Laporan pertanggungjawaban sebagaimana dimaksud pada ayat (1) disampaikan paling lambat 3 (tiga) bulan setelah akhir tahun anggaran berkenaan yang ditetapkan dengan Peraturan Desa. Namun belum sesuai dengan PSAP No.01 dimana masih terkendala oleh adanya peraturan pencatatan buku kas umum yang sering berubah-ubah setiap tahunnya. Pelaporan pertanggungjawban keuangan Desa Pentadio Timur belum sepenuhnya sesuai dengan PSAP No. 01 dimana Desa baru membuat empat dari tujuh aturan pelaporan pertanggungjawaban keuangan Desa yaitu 1) Laporan Realisasi Anggaran, 2) Neraca, 3) Laporan Arus Kas, sementara dalam aturan Penerapan PSAP No.01 meliputi tujuh aturan, yaitu: 1) Laporan Realisasi Anggaran (LRA) 2) Laporan Perubahan Awal Saldo Anggran Lebih 3) Neraca 4) Laporan Operasional 5) Laporan Arus Kas (LAK) 6) 
Laporan Perubahan Ekuitas, dan 7) Catatan atas Laporan Keuangan.

\section{SARAN}

Berdasarkan hasil penelitian dan kesimpulan di atas maka saran yang dapat penulis berikan agar Penerapan Pernyataan Standar Akuntansi Pemerintahan (PSAP) No.1 Dalam Pertanggungjawaban Keuangan Desa Di Desa Pentadio Timur, Kecamatan Telaga Biru, Kabupaten Gorontalo terlaksana sesuai dengan PSAP No. 01 yang berlaku, yaitu:

1. Pihak Pemerintah

Diharapkan Pemerintah dalam membuat laporan pertanggungjawaban keuangan Desa sesuai dengan Peraturan Pemerintah Nomor 71 Tahun 2010 berdasarkan PSAP No.01 dengan melengkapi komponen-komponen laporan keuangan guna menciptakan laporan keuangan yang akuntabel dan trasparan.

\section{Pihak Masyarakat}

Sebaiknya masyarakat perlu ikut andil dalam pengawasan pertanggungjawaban keuangan Desa, agar terciptanya laporan keuangan yang transparan dan akuntabel.

\section{Bagi Peneliti Selanjutnya}

Bagi peneliti selanjutnya yang akan melakukan penelitian tentang Penerapan Pernyataan Standar Akuntansi Pemerintahan (PSAP) No. 01 disarankan agar lebih memdalami fokus masalah yang diteliti serta mengkaji teori lebih dalam.

\section{REFERENSI}

Apriyono, Andri. (2010).Arti Penting Laporan Keuangan. Jurnal ilmu managemen

Direktorat Jendral Perimbangan Keuangan.(2017). Buku Pintar Dana
Desa, Dana Desa Untuk Kesejahteraan Rakyat. Jakarta Pusat 10710. www.djpk.kemenkeu.go.id

Lubis, S.M.Y. (2019) dengan judul Penerapan Standar Akuntansi Pemerintahan Dalam Pertanggungjawaban Keuangan Desa (Studi Kasus pada Desa Usortolang Kecamatan Kotanopan Kabupaten Mandailing Natal)

Renyowijoyo Muindro (2008). Akuntansi Sektor Publik Organisasi Non Laba, Mitra Wacana Media Jakarta.

Sako.U, F.Lantowa. (2018). Pengaruh penerapan standar akuntansi pemerintahan terhadap kualitas penyajian laporan keuangan pada pemerintah kabupaten gorontalo. Journal of accounting science EISSN 2548-3501.

Undang-undang Nomor 15 Tahun 2004 tentang Pengawasan dan Pertanggungjawaban Keuangan

Peraturan Pemerintah Nomor 24 Tahun 2005 tentang Standar Akuntasi Pemerintah

Peraturan Pemerintah Nomor 71 Tahun 2010 Tentang Standar Akuntansi Pemerintahan No.01

Peraturan Menteri Dalam Negeri Nomor 113 Tahun 2014 tentang PengelolaanKeuangan Desa.

Peraturan Menteri Dalam Negeri Nomor 20 Tahun 2018 tentang Pengelolaan Keuangan Desa Pasal 70

Peraturan Menteri Dalam Negeri Nomor 20 Tahun 2018 tentang Pengelolaan Keuangan Desa Pasal 71

Peraturan Menteri Dalam Negeri Nomor 20 Tahun 2018 tentang Pengelolaan Keuangan Desa Pasal 72 